\title{
RUSSIA'S RELATIONS WITH GULF STATES AND THEIR EFFECT ON REGIONAL BALANCE IN THE MIDDLE EAST*
}

\author{
M. Almaqbali \\ Peoples' Friendship University of Russia (RUDN University) \\ Miklukho-Maklaya str. 6, Moscow, Russian Federation, 117198
}

\begin{abstract}
The article reviews the history of formation and development of Russia's diplomatic relations with the Arab Gulf States. It analyzes the countries' rapport in the framework of the Cooperation Council for the Arab States of the Persian Gulf on the issue of homeland security in the region (the Iranian and Syrian questions, Qatar crisis). It also looks at the development of military and technical cooperation and the evolution of economic relations, which Russia uses to secure its growing geopolitical influence in the Arabian Gulf. The research describes the prospects of political development after the withdrawal of Russian troops from Syria.
\end{abstract}

Key words: Arabian Gulf, GCC, Syria, Saudi Arabia, Qatar

Russia began making contact with Gulf States back in 1932, when the USSR became one of the first countries that formally recognized Saudi Arabia and established diplomatic relations with the state. Shortly after, due to the change in the Soviets' party line (conversion to a new ideology and development of a moderate stance towards regional conflicts), the relations were suspended. The aggravation of international relations in the region was also the result of the competition between the Great Powers, and their respective political ambition. In the light of "West_-East" political-military confrontation, the Soviet Union took immediate interest in the latest regional developments.

During the Cold War, the Soviet government viewed Gulf States as the United States' allies, and consequently, Moscow's adversaries. The Kremlin-Riyadh relations became especially strained after the introduction of Soviet troops on the territory of Afghanistan. In 1990s, the Kingdom's support of separatism in Kosovo and Chechnya became a large stumbling block in the two states' relations. At the time, however, due to a growing rapport between Moscow and the West, Russia-Saudi Arabia relations shifted to the background of the global arena.

In the 2000s, Russia renewed its rapprochement with Gulf States, which was based primarily on mutual economic interests. In 2006, when Russia served as a host nation for a G8 summit for the first time, Moscow leaders suggested including problems of "energy security" in the agenda for negotiations and declared their determination to play a key role in this sphere across the globe and, in particular, in Eurasia. They also came

* Перевод с русского языка на английский выполнил д.п.н., доц. В.Г. Иванов.

Translation from Russian into English made by PhD, Assoc. Prof. V.G. Ivanov. 
up with the concept of an "energy superpower", describing Russia as such, and stated that this is how Moscow would like to be perceived by its G8 partners. The reaction of the leading states of the globe was immediate and extremely negative. Thereafter, the Russian government never officially referred to this concept again. At the same time, a number of policy documents in various fields of homeland security approved by Russian President Vladimir Putin after 2006, were based on the recognition of overriding importance of the energy sector in Russia's growing economic power. Russian policy in the energy sector is also driven by the need to control "key positions" in order to guarantee the country's economic security and maintain its status as a nuclear superpower [12]. In spite of having large energy resources, the Persian Gulf monarchies are greatly dependent on the oil market, and, essentially, they have to face the same challenges as Russia.

The Kremlin and Gulf States have been conducting a political dialogue as well: there have been five meetings at foreign secretary level, in the course of which multiple political issues have been discussed, including problems of global terrorism, the Iraq, Libya and Yemen national crises, and, finally, the Iran question. An important contribution to strengthening Russian-Iranian relations was the 'Treaty on the Basic Principles of Cooperation between the Russian Federation and the Islamic Republic of Iran, 'signed by the countries' presidents on March 12, 2001 in Moscow (the treaty came into effect on April 15, 2002). Russian-Iranian political dialogue is based on similar views on a majority of vital issues on both the global scale and the regional level, in particular, building multi-polar world order, reinforcing the United Nations' role in international affairs, combatting new challenges and threats, Syrian and Iraqi crisis regulation, and the Afghanistan situation. Gulf countries consider Tehran a major threat to their national security, as Iran has a powerful army and can count on the loyalty of Shia Muslim communities that live in GCC member countries.

It should be noted that in the Persian Gulf States, there are two major branches of Islam, Sunni and Shia, the adherents of which are in constant conflict and populate the region unevenly. Shia Muslims constitute only 15\% of the world's Muslim population, but the vast majority of the Shias live in Gulf States; Sunni Muslims, constituting $80-85 \%$ of the world's Muslims and compete with the Shias for power. Shia Muslims hold power in Iran and, recently, Iraq. The Sunni regimes of the Persian Gulf (specifically Kuwait, Qatar and the United Arab Emirates) fear the "Shia-Iranian threat". Moreover, it is essential to know that the population of Saudi Arabia is a Wahhabi majority, and they are much different from the Sunnis. Wahhabism is an ultra-extremist, violent ideology. Strategically, pro-Iranian Shia axis is supported primarily by China and Russia. The West, on the other hand, following the Cold War logic, aids the Sunni Muslim center line, which is directed against Syria and its Iranian allies. According to some experts, the "Shia vs. Sunni" conflict has no religious basis, instead it is a game of political interests, the objective of which is to provoke a conflict between the Iranians and Arabs. Experts also suggest that the fundamental differences between Saudi Arabia and Iran have nothing to do with their belief systems [9].

The "Arab Spring" made Gulf States address the issue of national security with a renewed vigor. A collision of Iranian and Saudi Arabian forces resulted in a series 
of uprisings in Egypt, Syria and Iraq. Arab media, namely the newspapers "Al Jazeera", "News" and "Opinion" have aired their suspicions that the United States is the main culprit behind the events in the Arab world. Among other things, the media argued that the USA has exhausted its military and financial resources in the Gulf region and will be forced to "abandon" the Middle East due to outrageous military expenditures. U.S. oil corporations, operating in the Gulf, realize that they need to vacate the "occupied" territories in such a way that nobody could "oust" them, and that the zones of interest would remain under control of the manageable forces. These "manageable forces" are Islamic hard-liners, sponsored by the United States and their allies in Saudi Arabia and Europe. Thus, according to the academic advisor of the RAS (Russian Academy of Science) Oriental Institute, Professor V.V. Naumkin, armed violence at the behest of global actors has played a fundamental part in the overall Gulf crisis [7]. At the same time, the growing crisis in Turkey, aggravated by its deteriorating position on the global arena, cast a long shadow on its example of "Islamic democracy" [1]. Many European NATO leaders expressed their discontent with the President of Turkey. Some of them believed that it was Erdogan who provoked European migration crisis after his failure to eradicate smuggling of refugees across the country's border. Turkey's renewed rapport with Moscow antagonized Washington, as it feared that Ankara might take the path of European integration and leave the NATO's military alliance.

Modern Russia-Gulf State relations have a great potential for strategic development, however, due to the existing contradictions, there is a number of obstacles on the way to this strategic partnership. Two main stumbling points between Russia and the Gulf Arabs are Iran (whose relations with Moscow are progressing) and the Assad regime (Qatar and Saudi Arabia made colossal investments to support Syrian rebels, while Russia is lending political, economic and military support to the ruling regime). For instance, the emirate of Qatar supplied arms to rebel armies, operating in the north of Syria, while Saudi Arabia gave ammunition to militants in the south [5].

Starting from 2012, the Gulf Cooperation Council (GCC) members steered a course towards increasing aid to the Syrian opposition. Financial flows intended for support of the insurgent army kept growing. In 2012 - 2013, Qatar alone allotted around three billion US dollars to the Syrian rebels, which significantly exceeded other countries' aid [6].

Within the context of the Syrian conflict, it is important to remember the concept of the "Greater Middle East", introduced by George W. Bush's administration in November 2003. This concept is based on the idea of democratization and reconstruction of the Middle East and Northern Africa, as opposed to the former U. S. policy supporting authoritarian regimes for the sake of regional stability and security, which fell short of the target. The introduction of the "Greater Middle East" initiative was treated as an attempt to interfere in the Gulf Arabs' internal affairs and sparked a backlash. As a counter to the American concept, at the League of Arab States' (LAS) summit, which was held in Tunis in May 2004, Egypt, Saudi Arabia and Syria introduced their own initiative of "self-democratization"; however, the discord of opinions during the meeting left the Arab governments in disarray. 
Upon completion of the Russian military operation in Syria, the GCC countries, seemingly have taken a 'wait and see' attitude to the Syrian situation, which is unlikely to change in the near future. This position appears to be aligned with Gulf States' waiting game in response to U.S. President Donald Trump's commitment to create safety zones in Syria. The Arab states seem to be staking on Russian participation, considering the global dimension of the conflict.

At the present stage, Russia is striving towards sustainable partnership in security matters with the member states of the GCC (the Gulf Cooperation Council or, more formally, Cooperation Council for the Arab States of the Gulf), which was established in 1981 at a summit of the leaders of Bahrain, Qatar, Kuwait, the UAE, Oman and the Kingdom of Saudi Arabia (KSA) in Abu Dhabi. Riyadh was one of the primary initiators of this regional military-political alliance. The organization's main objective is cooperation between the member states. The Secretariat General is located in Riyadh, Saudi Arabia. It is noteworthy that originally the GCC was controlled by Saudi Arabia. The Council countries have established strong ties with the chief NATO member, the USA, which supplies weapons to Gulf States, provides training to the states' troops and builds military bases on their territory. In 2014, this cooperation was officially documented: on December 11, the Cooperation Council for the Arab States of the Gulf signed an agreement with NATO, in which the two organizations made arrangements on safeguarding the supply of energy resources to the world markets. One should mention internal disagreements among the GCC members: in 2014, the organization experienced a rift between member states, with Saudi Arabia and Bahrain on one side. and the UAE and Qatar on the other. In 2017, the Ministry of Interior of Qatar announced the possibility of the Emirate's withdrawing its GCC membership.

Since the beginning of the Syrian war in 2011, Russia-GCC relations headed downhill due to a disagreement regarding the fate of Syrian president Bashar Al-Assad. Russia offered unqualified support for Assad, claiming that Syria's Ba'ath regime is a stronghold of resistance to Islamic extremism. However, the Cooperation Council for the Arab States of the Gulf, anchored by Saudi Arabia, was strongly pushing for Assad's expulsion, as his exit would facilitate mitigation of Iran's regional influence. Iran is Russia's key partner in providing the protection of Assad's regime and expansion of Russian hegemony over the Levant. Such discordance, in combination with RussianSaudi combat over oil prices, has led many experts on the Middle East to the conclusion that Russia-GCC relations is at their historic low [3].

However, upon a second glance at the geopolitical dynamics in the Middle East, one can clearly see that the assumption that Moscow-Gulf relations are experiencing crisis is misleading. In fact, one can contend that after President Putin's third re-election in 2012, Russia's geopolitical influence and 'soft power' in the Gulf States is growing. Through expanding its investment connections and undertaking certain diplomatic efforts, Russia is trying to win back the USSR positions in the regional policy, increase its role and influence on the distribution of power in the Middle East.

In 2015 and the first half of 2016, Russia was visited by the leaders of Kuwait, Qatar and Bahrain, as well as by Ministers of Foreign Affairs and other high-ranking officials of Gulf States. Almong the negotiating points were not only the Middle East 
regional problems, but also prospects of Russia-Gulf States bilateral relations. The analysis of the speeches delivered by the parties revealed that economic arrangements were not at the center of discussion. The bulk of the discussion revolved around the Syrian question. Despite the efforts of the Gulf Arabs to arrive at an understanding on the Syrian question, Moscow's position was unshakable.

In late May 2016, the fourth round of Russian-GCC strategic dialogue took place in Moscow. According to the joint final communiqué, "both parties share intentions to strengthen and develop rapport and partnership within the framework of strategic dialogue between Russia and the GCC'. The parties expressed their intention to continue cooperation in order to achieve general consensus and shared vision on international and regional problems of mutual interest and intensify their active collaboration in economic and humanitarian spheres. In the course of negotiations, Russian and GCC leaders outlined the areas of potential partnership: counter-terrorism efforts, and the monitoring of nuclear energy uses. Despite having mutual economic and political interests, the parties failed to reach an agreement on the Syrian question.

The GCC Summit of December 7-8, 2016 in Manama confirmed the Gulf leaders' position regarding the Syrian crisis: they recognized the need to reach its political settlement, however, sans President Assad. With the participation of British Prime Minister Theresa May, the Council and the UK were able to formulate a joint statement, which read: "It is necessary to achieve a sustainable political resolution in Syria that ends the war and establishes an inclusive government that protects all ethnic and religious communities, and preserves state institutions". The leaders also reaffirmed that "Assad has lost all legitimacy and has no role in Syria's future". They also highlighted that "The international community needs to be united in calling for the Assad regime and its backers, including Russia and Iran, to support a meaningful end to the violence, sustained humanitarian access, and an inclusive political process. The solution to the situation in Syria is an enduring political settlement based on transition away from the Assad regime to a government representative of all Syrians; and with which we work to fight terrorism" [6].

Oman and Kuwait are two GCC member states that were the most enthusiastic about Russia's proposition to settle the Syrian conflict without excluding Assad. Oman's position is justified by the fact that, throughout history, it has played a mediating role, trying to maximize its influence in the region. On October 26, 2015, Minister of Foreign Affairs of Oman, Yusuf bin Alawi, held a meeting with Assad. As was reported by the Syrian Arab News Agency (SANA), the Syrian leader thanked Oman for "the sultanate's sincere efforts to help Syrians realize their aspirations in a way that preserves the country's sovereignty and territorial integrity". "Defeating terrorism will promote Syria's political recovery" said Assad [5].

Furthermore, during the negotiations on the Iran Nuclear Deal in 2014, Oman strongly supported a thaw in relations between Iran and the USA. The recent developments indicate that Masqat is able to raise its international profile by means of diplomatic efforts. While Oman remains a peripheral player in the Persian Gulf, any support by GCC members is viewed as a diplomatic victory by Russia, as it fortifies the expanding coalition of the League of Arab States' members standing for political settlement of the Syrian 
conflict. For example, on November 2, 2011, the LAS announced a peace plan for Syria, according to which the League's inspectors were supposed to launch their mission in the country. However, the Syrian regime was not prepared to start negotiations with the opposition. Another demarche undertaken by the GCC states was initiating the General Assembly Third Committee's resolution condemning human rights violations in Syria, including violent acts against the participants of massive protests. The resolution was approved by the majority of votes in late November, 2011.

The Arab States' further efforts were directed towards increasing pressure on the incumbent Syrian government. In February 2012, Gulf States began suspending their diplomatic relations with Syria and deporting Syrian diplomats. Moreover, prompted by the Gulf countries, the LAS sponsored a UN Security Council resolution calling for immediate cease-fire in Syria. On February 4, 2012, the resolution was vetoed by Russia. The parties assumed similar positions concerning the UNSC resolution of June 19, 2012, which solicited extending the mandate of the United Nation Supervision Mission in Syria and demanded that Syrian government should end armed encounters with the opposition. The Persian Gulf States accused the United Nations of an inability to make a decision which would have stabilized the situation in Syria. In June 2013, Saudi Arabia gave up its membership as a nonpermanent member of the UN Security Council, demonstrating its dissatisfaction with the development of the Syrian situation. Its allies, the Arab monarchies, supported the KSA's decision [6].

Kuwait developed a unique attitude to the Syrian question by assuming an intermediary role between Saudi Arabia and Russia. Acting in accordance with the GCC consensus, it sympathizes with Syrian rebel groups. As was noted by Daniel DePetris in National Interest, Kuwaiti donors provide zealous support to Assad's adversaries in Syria, including allocating generous funds to sustain Al-Qaeda's local branch, the so-called "Al-Nusra Front", and its militias [2]. Conversely, by mid-2015, Kuwait backed Russia on its plan for comprehensive political settlement of the Syrian conflict and criticized Riyadh's hostility towards Assad.

Just as in the case with Kuwait and Oman, Russia has made certain progress on its way to a consensus with Abu Dhabi. On June 3, 2016, the speaker for the UAE Federal National Council spoke favorably of Russian Minister of Foreign Affairs Sergey Lavrov's active position in promoting peace talks in Syria. The UAE high-ranking officials also expressed their readiness to settle the Syrian issue with the participation of all major political players, including President Assad. Abu-Dhabi's changed outlook indicates Russia's strong hand in the game, as it is able to steer the GCC members away from Riyadh's hegemony.

Thus, the balance of powers in the GCC has shifted, but not in Saudi Arabia's favor: the country's inefficient policies, both on domestic and global scale, have left the country in a disadvantageous position.

In this context, political tensions created by the House of Saud and its allies, specifically the UAE, Bahrain and Egypt, in relation to Qatar, have caused a major disintegration among the KSA-governed GCC members, which, in its turn, has led to Saudi Arabia's isolation in the regional arena. 
Saudi Arabia's recent militarism has triggered protests among certain GCC members. The member states' overt disgruntlement with the KSA - Oman's and Kuwait's among others - as well as Qatar's current unambiguous anti-Saudi attitude indicate a new development in the Arab world. Present tensions in Saudi-Qatar relations, particularly Doha's objection to Riyadh's discreditable and appalling stipulations, on the one hand, and Oman's opposition to the Saudi initiative to create the Gulf Cooperation Council, on the other, clearly show that the Kingdom's leaders have no clue about the GCC's future development. The discontent member states see the GCC as a Saudi tool for expanding the Kingdom's influence in the region and do not wish to continue their cooperation with the Council. Considering the recent developments, many experts in political science believe that Saudi Arabia outplayed itself in a reckless political gamble that they themselves initiated.

Eventually, Saudi Arabia became ostracized on the regional level, with but a few Arab allies supporting the Kingdom's anti-Qatar policy. At the same time, the Wahhabi regime's support for terrorist groups sparked outrage in the global community. Saudi Arabia' recent policies not only aroused indignation both in the region and the world, but also affected its internal affairs.

By restoring its diplomatic rapport with Oman, Kuwait and the UAE and reaching an agreement on the Syrian question with the GCC, Russia formed a coalition creating a counterbalance for the Saudi-Qatar alliance. While boosting its diplomatic activity in the Persian Gulf, Russia is working towards strengthening its ties with Algeria, Iraq and Egypt. Using Moscow's growing influence in the Middle East, Russian President Vladimir Putin is trying to shift the balance of power in the Council in Russia's favor and keep Saudi Arabia and Qatar in political isolation.

To further damage Riyadh's position in the Gulf, Russia is trying to strengthen its diplomatic ties with Manama, although Bahrain is essentially a Saudi satellite state. Saudi Arabia is Bahrain's major trade and economic partner, with 29.1\% of Bahraini import being purchased by the Saudis [11]. Bahrain, in its turn, has always supported Riyadh in its opposition to Iran. At the same time, Manama signed a deal with Moscow, securing supply of Russian weapons to Bahrain, and is openly discussing RussiaBahrain anti-terrorism cooperation while ignoring Riyadh's discontent. Having Bahrain on its side, the Kremlin is celebrating its diplomatic victory in the region. Meanwhile, Saudi Arabia is losing its leverage in the Gulf.

Saudi Arabia's deteriorating position in the region forced King Salman to soften his stance in regards to Assad's immediate removal, agree to the LAS consensus on Syria and renew his diplomatic rapprochement with Russia. Russia-Saudi bilateral rapprochement was a gradual process, since Riyadh was still suspicious of Moscow's intentions. Many Saudi politicians feared that Moscow will side with Assad and would decide to launch a military intervention in September 2015. Saudi Arabia's hostile attitude to Russia was reinforced by the fact that Russian military involvement in Syria began just a few weeks after the Moscow-Riyadh negotiations. After the Arab League reached a consensus on the Syrian question and decided in favor of its comprehensive political settlement, Saudi Arabia put the discrepancies aside and agreed to a compromise with Moscow. 
It appears to be unlikely that Russia will provide a substantial and long-lasting competition for Saudi Arabia's hegemony in the Council, but the strengthened diplomatic ties between Moscow and Riyadh's closest allies will increase Russia's leverage in the GCC and induce other Council members to join in with Russia on the Syrian question. The fact that Riyadh moderated its belligerent anti-Assad attitudes and resumed a political dialogue with Russia became obvious after the "historic" visit of King of Saudi Arabia Salman bin Abdulaziz Al Saud in Russia in the fall of 2017. It was the first official trip to Russia by a reigning Saudi monarch in the history of MoscowRiyadh's relations. This unexpected rapprochement between the two foes ran contrary to regional analysts' predictions, who were setting the odds on the continued controversy. King Salman's visit heralded a new page in Saudi-Russia relations and took the rapport between the two countries to a new level.

At present, Saudi Arabia found itself in a tough geopolitical situation. On the one hand, the Kingdom faces Iran's increased influence on the Arabian Peninsula and in the region in general. "Hezbollah", the Assad regime, the Shia opposition in Bahrain, and the Houthi insurgency in Yemen (allegedly) are all supported by Tehran. On the other hand, the United States' ambiguous policy in Egypt (the implicit consent to Hosni Mumbarak's resignation and attempts to ingratiate itself with "Muslim brothers") and Syria, complete with the Iran nuclear deal, causes Riyadh to doubt the reliability of an American "safety umbrella". After Donald Trump took his "America First" foreign policy approach to the United Nations and promised not to impose American values on other countries, Moscow's positions in the Arab world have established a foothold: Russia comes across as an appealing partner for the Arabs, as it appears to be a strong player, capable of holding Iranian interests in check.

The 2015 Iran Nuclear Deal raised concerns in the USA, as well as among certain Arab States, that making concessions will only fuel Tehran's ambitions. The supporters of the Deal, however, argued that it will strengthen the position of the rightwing Iranian political elite and make Iran's regional policy less reckless. As President of Iran Hassan Rouhani pointed out, after the agreement between Iran and the P5+1, his country is no longer feared by the global community.

Despite the differences of opinion on the Syrian question and Russia's active participation in the Nuclear Deal, the relations between Russia and Gulf States are headed in the right direction: aside from economic cooperation, the parties are engaged in an active dialogue, discussing such key global problems as international terrorism, piracy, and drug trafficking.

Russia is reinforcing its political, military and economic ties with Qatar, Oman, Kuwait, and the UAE, trying to create an equipoise to Saudi Arabia's hegemony in the Persian Gulf. These connections are helping to settle the differences that had been impeding productive collaboration between Moscow and Arab states for decades.

Russia's economic interests in Qatar demonstrate how closer trade ties can ease deep-rooted hostility. The assassination of high-profile Chechen politician Zelimkhan Yanderbiyev in Doha in 2004, as well as Qatar's support for separatists, significantly damaged Russian relations with the monarchy. However, Russia is trying to establish 
common grounds with Qatar through their partnership in the energy sector. Russian energy giant "Gazprom" is expanding its cooperation with "Qatargas" in production of liquid gas. "The Russian Private Equity Fund is carrying on active cooperation with the Qatar Investment Authority. \$1.2 billion has already been invested in certain projects, while other projects of about $\$ 12$ billion total worth are pending", reported Minister of Energy of the Russian Federation Alexander Novak [8].

In response to Russian Energy Minister's 2016 appeal to raise annual trade volume between Moscow and Doha to \$500 million, Minister of Energy of Qatar Mohamed bin Saleh al-Sada stressed the importance of forging stronger trade ties and enhancing bilateral economic cooperation between Qatar and Russia's private and state sectors. A balanced approach, established by Qatar years ago, to maximize its influence in the region, demonstrates that expanding its economic ties with Russia is an intelligent game plan for Doha. Therefore, Russia has a perfect opportunity to establish an economic foothold in the Persian Gulf state, which, historically, was least friendly to Moscow.

Similar trends can be traced in Russia's relations with other Gulf States. According to President of Moscow Institute for Middle East Studies Yevgeny Satanovsky, Oman's trade ties develop independently from large-scale geopolitical events in the Middle East. Muscat's economic autonomy allowed to increase the trade volume between Russia and Oman from $\$ 13$ million in 2010 to $\$ 100$ million in 2014 [10]. Oman supports Russian security initiative in the Gulf, and Moscow, in its turn, appreciates Muscat's pragmatic outlook on the Syrian situation.

Russia's relations with the UAE have been fortified through economic investments. Emirati corporations invested funds in the construction of facilities for the 2014 Olympics in Sochi and a major port outside Saint Petersburg; they also subsidized Russian oil giant Rosneft for the upstream project. The established partnership between Russia and Kuwait, Moscow_-Manama growing economic interaction, as well as the UAE investments into the Russian economy indicate strong Russian presence on Saudi Arabia's traditional turf. "For the year 2016, bilateral trade between the two countries reached $\$ 1.2$ billion, the same level as in 2015 but the figure is expected to go up this year as ties between the two countries strengthen and the UAE imports more goods from Russia", said Ara Melikyan, a trade representative of the Russian Federation in Abu Dhabi [13].

Besides attracting generous investments from the Persian monarchies, one of the key elements of Russia's agenda in the region is to increase geopolitical influence through military contracts. According to the Federal Service for Military-Technical Cooperation (FSMTC), while Qatar intends to purchase Russia's S-400 anti-missile systems "Triumph" and "Pantsir-C", Moscow is negotiating a deal planning to arrange a supply of Su-35 air-defense fighters to the UAE [4].

After Russia withdrew its troops from Syria, the power landscape in the Persian Gulf has changed, opening new possibilities for political development in the region. In particular, Russia and Saudi Arabia have travelled a long path of negotiations regarding the Syrian question, resulting in their bilateral rapprochement, despite certain discrepancies, primarily regarding Bashar Al-Assad's fate. Moscow gives credit to Riyadh, 
acknowledging its vital role in the Cairo agreement between Russia and Syrian opposition, which allowed creation of de-escalation zones in Ghouta and Al-Rastan.

It is noteworthy, that Saudi-Arabia's attitude towards Syria has significantly evolved. Formerly, the Kingdom was strongly pushing for Assad to step down, in congruence with the Obama administration's position. However, when Donald Trump took office, the Saudi leaders quickly 'changed trains' and agreed that a peaceful way of solving the Syrian problem was of paramount importance (that, of course, would include removing Assad from the picture). The necessity of the political settlement of the issue was repeatedly highlighted by Saudi Arabia's Minister of Foreign Affairs Adel bin Ahmed Al-Jubeir, which in its turn fostered Russian-Saudi rapprochement.

The 2017 Qatar crisis also played an important part in the formation of new alliances in the Gulf. Russia assumed a balancing approach, maintaining important economic relations with both sides: the Qataris and the Saudis.

Thus, Russia has secured its image as a strong player on the Middle Eastern arena, whose support can shift the balance of power on the Arabian Peninsula. Depending on the situation, this support may be of political, economic or military nature, provided all interests are considered and long-term arrangements are established.

Russia's key priority in the region is fighting the Daesh and other radical Islamic militant groups. Difference of attitudes often causes controversy between Russia and Gulf States; that is why it is highly unlikely that Moscow will change its geopolitical priorities and terminate the long-established and successful cooperation with Iran, a prospective member of the SCO (Shanghai Cooperation Organization), in favor of its rapprochement with the Gulf Arabs. At the same time, it is doubtful that Russia-Iran partnership will further evolve: Iran's support for Hezbollah and Yemen rebels, as well as its high regional ambitions, have been getting in the way of the two countries' harmonious relations. Due to its cooperation with Israel in the field of security, and its neutral stance towards Tehran's allies in Syria and Yemen, Moscow cannot back Iran on some of its more extreme policies. Besides, Russia wishes for Iran to maintain its denuclearized status [5].

In the changing world, Moscow's allies are not necessarily Washington's foes, and vice versa. Cooperation between Russia and Gulf States is based on their shared interests, in particular, fighting international terrorism.

Communication between Russia and Gulf States regarding the Syrian problem was progressing rather unevenly. The sides adopted diametrically opposed positions in respect of the incumbent president's fate and in regards to which Syrian opposition groups should be considered moderate. At the same time, both Russia and the Gulf Arabs were seeking settlement to a conflict which destabilized the regional situation and boosted the threat of terrorism. Russia and Gulf States concur on the future of Syria's state system, supporting its territorial integrity, secular identity and protection the rights of ethnic and religious minority groups. The two parties are also united by the common goal of combatting world terrorism, in particular the Islamic State, the liquidation of which is seen as the priority mission of the global anti-terrorist campaign. 


\section{Комментарий переводчика:}

Статья М. Аль-Макбали посвящена актуальной проблеме и представляет значительный интерес как для российских, так и для зарубежных читателей, что объясняет оправданность перевода статьи на английский язык. В статье представлен содержательный авторский анализ развития отношений России со странами региона в историческом, дипломатическом, экономическом, военном и геополитическом аспектах. В процессе перевода были сохранены и подчеркнуты важные аспекты авторского научного текста. Так, например, для автора имело принципиальное значение использование понятия «Арабский залив» вместо «Персидский залив». Статья содержит оригинальные и значимые выводы и прогнозы и может быть интересна для международного читателя.

\section{REFERENCES}

[1] Aksenenok A. Rossijskij vzglyad na Persidskij zaliv i iranskuyu problem [Russian Outlook on the Persian Gulf and the Iranian Problem]. Islam Today. 20.03.2017. Available from: http://islam-today.ru/islam_v_mire/bliznij-vostok/rossiassagpz-razvitie-otnosenij-posle-adernojsdelki-s-iranom/. Accessed: 09.07.2018 (In Russ.).

[2] DePetris D.R. Why America Can't Win in Syria. National Interest. December 19, 2017. Available from: https://nationalinterest.org/feature/why-america-cant-win-syria-23721. Accessed: 09.07.2018.

[3] DePetris D.R. Why Syria Could Become the Black Hole of the Middle East. The National Interest. 5.12.2018. Available from: https://nationalinterest.org/blog/the-skeptics/whysyria-could-become-the-black-hole-the-middle-east-23506. Accessed: 09.07.2018.

[4] Iskanderov P. Rossiya i Persidskij zaliv: okna vozmozhnostej [Russia and the Persian Gulf: Windows of Opportunity]. Strategic Culture Foundation. Electronic edition. 06.09.2017. Available from: https://www.fondsk.ru/news/2017/09/06/rossia-i-persidskij-zaliv-oknavozmozhnostej-44604.html. Accessed: 09.07.2018 (In Russ.).

[5] Mahmood O. View from the Gulf. Bahrain Center for Strategic, International and Energy Studies ("Dirasat"). 16.05.2018. Available from: http://www.derasat.org.bh/. Accessed: 09.07.2018.

[6] Melkumyan E. Rossiya i strany persidskogo zaliva v kontekste sirijskogo krizisa [Russia and the Gulf Countries in the Context of the Syrian Crisis]. Carnegie Endowment for International Peace. 19.12.2016. Moscow: 2-6. Available from: http://carnegieendowment.org/. Accessed: 09.07.2018 (In Russ.).

[7] Naumkin V. "Arabskaya vesna" i global'naya mezhdunarodnaya sistema [The Arab Spring and the Global International System]. Rossiya v global'noj politike. 02.08.2011. Available from: http://globalaffairs.ru/number/Snizu-vverkh-i-obratno-15277. Accessed: 09.07.2018 (In Russ.).

[8] Rossiya i Katar zadumalis' o realizacii proektov na 1,2 milliardov dollarov [Russia and Qatar Contemplate \$1.2 Billion Worth Projects]. TASS. 16.05.2018. Available from: http://itar-tass.com/. Accessed: 09.07.2018 (In Russ.).

[9] Sadjadi R. SHiity i sunity [The Shias and Sunnis]. Available from: http://xn--80aplilbp.xn-p1ai/sunit-hiity.html. Accessed: 09.07.2018 (In Russ.).

[10] Satanovsky E. Saudovskaya Araviya bez soyuznikov [Saudi Arabia Without Allies]. Vipvideoclub.ru. 18.10.2016. Available from: http://vipvideoclub.ru/stati/voina/evgeniisatanovskii-saudovskaja-aravija-.html. Accessed: 09.07.2018 (In Russ.).

[11] The World Factbook - Central Intelligence Agency. Available from: https://www.cia.gov/ library/publications/the-world-factbook/. Accessed: 09.07.2018.

[12] Tkachenko S.L. Koncepciya ehnergeticheskoj sverhderzhavy i otnosheniya Rossijskoj Federacii i Evrosoyuza v oblasti ehnergetik [The Concept of an Energy Superpower and Relations Between the Russian Federation and the European Union in the Energy Sector]. Quality Economics. 2014; 4 (8): 27-33 (In Russ.).

[13] OAEH-Rossiya. Torgovye svyazi [UAE-Russia. Trade Relations]. AbuDhabiTiming. 25.07.2017. Available from: http://abudhabitiming.com/2017/07/oae-rossiya-torgovye-svyazi/. Accessed: 09.07.2018 (In Russ.). 
DOI: $10.22363 / 2313-1438-2018-20-4-536-547$

\title{
ОТНОШЕНИЯ РОССИИ И СТРАН ПЕРСИДСКОГО ЗАЛИВА И ИХ ОТРАЖЕНИЕ В РЕГИОНАЛЬНОМ БАЛАНСЕ НА БЛИЖНЕМ ВОСТОКЕ
}

\author{
М. Аль-Макбали \\ Российский университет дружбы народов \\ ул. Миклухо-Маклая, 6, Москва, Россия, 117198
}

\begin{abstract}
В статье отражен исторический аспект установления и развития дипломатических отношений России с государствами Арабского залива, анализируется взаимодействие в рамках Совета сотрудничества арабских государств Персидского залива по вопросам безопасности в регионе (отношения по иранскому и сирийскому вопросу, катарский кризис), а также направления военнотехнического сотрудничества, развитие экономических связей, с помощью которых Россия пытается играть все более заметную геополитическую роль в Арабском заливе. Представлены перспективы развития политической ситуации после вывода российских войск из Сирии.
\end{abstract}

Ключевые слова: Арабский залив, ССАГПЗ, Сирия, Саудовская Аравия, Катар

\section{Сведения об авторах:}

Аль-Макбали Мазин Саид Мусабах - аспирант кафедры сравнительной политологии Российского университета дружбы народов (ORCID ID: 0000-0003-2695-5879) (e-mail: mazinalmaqbali@gmail.com).

Перевод выполнен: Иванов Владимир Геннадьевич - доктор политических наук, доцент кафедры сравнительной политологии Российского университета дружбы народов (ORCID ID: 0000-0002-3650-5460) (e-mail: ivanov_vg@pfur.ru).

\section{Information about the authors:}

Almaqbali Mazin Said Musabah - Postgraduate Student of the Department of Comparative Politics, Peoples' Friendship University of Russia (RUDN University) (Russian Federation) (ORCID ID: 0000-0003-2695-5879) (e-mail: mazinalmaqbali@gmail.com).

Translated by: Ivanov Vladimir Gennadievich - PhD, Doctor of Science, Associate Professor of the Department of Comparative Politics, Peoples' Friendship University of Russia (RUDN University) (Russian Federation) (ORCID ID: 0000-0002-3650-5460) (e-mail: ivanov_vg@pfur.ru).

Статья поступила в редакцию 20.07.2018.

Received 20.07.2018. 